\title{
Counseling ethics education for enhanced professional identity and development: guidance and counseling teachers lifelong learning acquisition empowered
}

\begin{abstract}
Counseling ethics competency is an essential part of counselor identity development as required by the counseling profession, and counseling ethics education is one major component of knowledge acquisition in counseling profession training standards. The purpose of this qualitative research was to conduct an interpretive case study to explore, understand, describe, and interpret how guidance and counseling teachers learn, understand, experience, and apply counseling ethics education to their evolving professional identity and development in the counselor education training program. The main author was the primary instrument for data collection and analysis. Coding categories were developed and tentative themes emerged, were refined, and became the five emergent master themes for this research: education foundation, education integration, education application, education assimilation, and education appreciation. The discussion and interpretation are grounded in the principles of effective adult learning in counseling ethics education; to empower lifelong learning acquisition among guidance and counseling teachers toward enhanced professional identity and development.
\end{abstract}

Keyword: Professional identity; Ethic education; Counseling professional; Counseling student; Counselor educator 